Stóhr Lóránt

\title{
Visszatérés a tett színhelyére. A holokauszt traumája Kádár-kori magyar dokumentumfilmekben
}

\begin{abstract}
Absztrakt
A tanulmány három Kádár-kori magyar dokumentumfilmben vizsgálja a holokauszt traumájának megjelenítését. Az Éva A 5116 (1964), valamint A látogatás (1982) és a Társasutazás (1985) címú filmeket összeköti, hogy egy-egy utazást állítanak a narratíva centrumába, amelyek a múltba, a trauma helyszínére vezetnek vagy a traumával történô szembenézésre késztetnek. A filmelemzések azt vizsgálják, hogy milyen alkotói stratégiák mentén értelmezik a holokauszt túlélooinek traumával történô szembenézését és megküzdését, milyen szerepet játszik a vészkorszak óta eltelt idô a szereplôk megküzdésében, valamint hogy az aktuális Kádár-kori emlékezetpolitika és a domináns dokumentumfilmes paradigma miként befolyásolta a múvek elkészítését és ábrázolási lehetôségeit.

\section{Szerzố}

Stôhr Lóránt (1974) az Élet és Irodalom filmkritikusa, a Színház-és Filmmúvészeti Egyetem docense. Szakterülete: filmmelodráma, Fassbinder életmúve, dokumentumfilm, kortárs film. E-mail: stohrlorant@szfe.hu

https://doi.org/10.31176/apertura.2019.15.3.2 


\section{Stóhr Lóránt}

\section{Visszatérés a tett színhelyére. A holokauszt traumája Kádár-kori magyar dokumentumfilmekben}

\section{Bevezetés}

A holokauszt traumájának reprezentálhatósága a múvészet gyakorlói és teoretikusai számára a táborok felszabadulása óta alapvetô kérdés. ${ }^{[1]}$ Ábrázolható-e a holokauszt? S ha igen, ki teheti meg és milyen múfajban? Kisantal Tamás könyvében Terrence Des Pres nyománn ${ }^{[2]}$ összefoglalja a holokausztkánon szabályrendszerét, amelynek része a holokauszt egyedi eseményként való feldolgozása, a szorosan vett valósághúség és a komolyság. ${ }^{[3]}$ A holokauszt ábrázolásának fenti konvenciórendszere egyenesen predesztinálja a sokáig a ,józanság diskurzusa" ${ }^{[4]}$ körébe utalt dokumentumfilm múfaját a téma feldolgozására. A pszichoanalitikus alapú traumaelméletek képviselôi (Cathy Caruth, Dori Laub, Shoshana Felman) másfelől a sokkszerú esemény adekvát ábrázolásának a nem folytonos narratívát, a töréseket, az elhallgatásokat, a kimondhatatlan kimondását tartják, ${ }^{[5]}$ ami ellene megy számos hagyományos dokumentumfilmes mód reprezentációs technikájának. Vajon akkor hogyan lehet képes a trauma reprezentálására? Finn Daniels-Yeomans jogosan teszi fel a kérdést, hogy „ha a traumatikus élmények széttörik a reprezentáció folyamatait, akkor hogyan kapcsolhatóak össze ezek a dokumentumfilm "alapvetôen« reprezentációs médiumán keresztül?”[6] A kilencvenes évek traumaelméletei számára a megtermékenyítô hatású, kiemelkedô példa Claude Lanzmann Shoah (1985) címú dokumentumfilmje, ami az egykor megélt érzelmek kijátszásán, újramegélésén, a tanúságtételen, a hiányok felmutatásán keresztül tud felmutatni, átélhetôvé tenni valami lényegit a trauma természetéból a befogadó számára.

A kelet-európai szovjet blokk országaiban a kommunista ideológia és a Szovjetunió vezetésének aktuális politikai érdekei tovább nehezítették a holokauszt ábrázolását. Magyarországon a kommunista vezetés tabukkal vette körbe a holokausztot, ami a filmmúvészetben a zsidóság szisztematikus kiirtásának elhallgatásához vezetett. „A vészkorszakról való beszédet a kommunista diktatúra tabuvá tette, illetve részben inautentikussá, amennyiben az »antifasiszta« ideológia keretébe helyezte."[7] Tanulmányomban három Kádár-korszakban készült dokumentumfilmet elemzek a holokauszt mint egyéni és kollektív trauma reprezentációja szempontjából: Nádasy László Éva A 5116 (1964), B. Révész László A látogatás (1982) és Gazdag Gyula Társasutazás (1985) címú múveit, vagyis egy hatvanas évekbeli és két nyolcvanas években készült alkotást. A mintegy 
húsz év különbség a két korszak között lehetôséget ad arra, hogy a holokauszt emlékezetpolitikai állásának, a traumatikus eseménytôl eltelt idô és a dokumentumfilm-múvészet aktuális reprezentációs stratégiáinak függvényében vessem össze a három alkotást, a holokauszt különbözô dokumentumfilmes reprezentációit. Az elemzés vezérfonalaként az utazásnarratíva szolgál: amíg a 60-as években az utazás a traumatikus esemény kísértetének visszatérése, egyfajta kísértetjárás, addig a 80-as években már részben tudatosan felvállalt fájdalmas gyászmunkából, részben megszállott ismétlési kényszerből eredô szembenézést hozó zarándoklat.

\section{Az utazásnarratíva a holokauszt-dokumentumfilmekben}

A holokausztirodalom egyik inherens motívuma az utazás, amely különféle kulturális értelmezéseket (halott világba tartó út, pokolra szállás, kifordított nevelődési történet) nyer az alkotásokban. ${ }^{[8]}$ A témáról szóló dokumentumfilmekben szintén gyakran megjelenik az utazás motívuma, amelynek alanyai általában a túlélók és/vagy leszármazottjaik. Annette Insdorf személyes dokumentumfilmeknek nevezi azokat az alkotásokat, amelyek „nyomon követik a túlélô visszatérését arra a helyre, ami már nem ismeri ôt, általában a magát a veszteséget jelentő szülôvárosba, vagy a még mindig a rettenet szagát árasztó koncentrációs táborba." ${ }^{[9]}$ A klasszikus holokausztirodalommal szemben a személyes dokumentumfilmben az utazások nem a deportálások történetének rekonstrukciójaként, jóval inkább a múltba vezetô utazásként értelmezhetôk. ${ }^{[10]}$ Az emlékezés - ami mindig szimbolikus utazás a múltba - valóságos utazással kapcsolódik össze a dokumentumfilmekben, az utazás az emlékezés médiumává válik.

Murai András és Tóth Eszter Zsófia nem a traumatizált utazó, hanem a filmkészítô és a befogadó szempontjából, a kollektív emlékezet megteremtésében játszott szerepét elemezve vizsgálják a holokauszt-dokumentumfilmek utazásnarratíváját. A szerzôpáros szerint „, traumatapasztalatátadás folyamatának fontos eleme az emlékezeti tér megjelenítése"[11], ezért a dokumentumfilmek az élmények elbeszéléséhez a holokauszt eseményeinek terét igyekeznek különféle módszerekkel felidézni a nézô számára. A szerzôk által azonosított négy különbözô módszer egyike a visszatérés, amikor a túlélôk, szemtanúk és áldozatok a kamera részvétele mellett felkeresik a holokauszt eseményeinek helyszíneit. „A hely funkciója ekkor az emlékek elôhívása, az érzések felidézése, a múlt eseményeivel való szembesítés." ${ }^{[12]}$ A továbbiakban a szerzôpárosnak ezt a megállapítását kívánom árnyalni, részletesen megvizsgálni, hogy mi történik a túlélókkel a különbözô esetekben, milyen szerepe van a trauma utótörténetében az utazásnak. A három film utazásai a múlttal való szembesülés különféle tapasztalatát hozzák el az utazók/emlékezók számára. Az Éva A 5116-ban egy szimbolikus utazást tesznek az emlékezôk azzal, hogy a múlt eleven kísértete tér vissza Auschwitzból az otthonaikba, $A$ látogatásban a túléló a trauma elôtti nosztalgiával átitatott otthonába próbál visszatérni, hogy ott azzal szembesüljön, a trauma széttörte a nosztalgia világát, végül a Társasutazás visszatérés a tett színhelyére, közösségi zarándoklat a szenvedések helyszínére. 


\section{Emlékezet- és filmpolitikai keretek}

A holokausztot a szovjet befolyás alatt álló kelet-európai országokban, azon belül Magyarországon erôs politikai elhallgatás vette körül. A demokratikus viszonyok hiányából következett a zsidók elpusztítására való emlékezés elfojtása. Az 1949-ben sztálinista diktatúrát kiépítố kommunista vezetés „a »fasiszta Magyarország « fordulatot a lakosság megfélemlítésére használta, és semmit sem kívánt kevésbé, mint a trauma oldását. A »zsidókérdést“ [...] számúzte a nyilvánosságból. Tabuvá tette."[13] Az 1956-os forradalom után berendezkedó, Kádár János vezette új hatalom a zsidóknak a korábbi sztálinista vezetésben való túlreprezentáltsága miatt az antikommunizmus és antiszemitizmus összekapcsolódását igyekezett a zsidókérdés elhallgatásával elkerülni. „A kádári Magyarországon tilos volt a zsidózás, de arról sem eshetett szó, hogy van-e antiszemitizmus, a zsidókérdés mint olyan, és annak bármelyik részeleme tabukérdéssé, áthidaltnak, megoldottnak vett problémává minôsült.."[14]

A zsidóságot övezó politikai tabuk miatt a három T cenzurális rendszerében a holokausztról sokáig kizárólag „túrt” alkotások születhettek, azok is sokáig csak az elōírt humanista ideológiai keretrendszerben. A játékfilmgyártásban tíz év telt el a magyarországi deportálások után, amikor végre 1954-1955-ben egy vígjátékban és egy felszabadulásról szóló drámában megjelent a holokauszt motívuma. A téma késóbb is csak a hatvanas évektól kezdve, a kultúra oldódó cenzurális keretei között kapott valamivel nagyobb hangsúlyt (Két félidô a pokolban. Fábri Zoltán, 1961; Nappali sötétség. Fábri Zoltán, 1962; Utószezon. Fábri Zoltán, 1967; Apa. Szabó István, 1966, stb). ${ }^{[}$ ${ }^{15]}$ Az erôs politikai kontroll alatt tartott magyar dokumentumfilmben egészen a hatvanas évek elejéig kellett várni a holokauszt tematikus megjelenésére, ami az évtizedben mindösszesen két alkotást jelentett (Éva A 5116. Nádasy László, 1964; Jelenlét. Jancsó Miklós, 1965). Az elsôsorban a jelenkor társadalmi kérdéseit tematizáló hetvenes évekbeli dokumentumfilmból szinte teljesen hiányzik a téma (egyetlen kivétel: Jelenlét II. Jancsó Miklós, 1978), és csak a nyolcvanas évek eleje és a deportálások negyvenedik évfordulója hozott látványos növekedést a vészkorszakról szóló nemfikciós alkotásokban (A látogatás, a Társasutazás, valamint az Endlösung. Fehéri Tamás, 1984).

Az államszocialista rendszer gyengülése már megengedte a történelmi tabutémák - részben illegálisan készülô (pl. Recsk. Böszörményi Géza - Gyarmathy Lívia, 1988), részben utólag betiltott (pl. Pócspetri. Ember Judit, 1982) - dokumentumfilmes reprezentációját a történelmi dokumentumfilm jelentôs hullámát eredményezve a nyolcvanas években. A magyar dokumentumfilm a nemzetközi trendekkel párhuzamosan a személyes tanúságtétel felé fordult, és a mindentudó narrátorok és megszólaltatott történészek értelmezéseit kerülve vagy mellékes szerepbe utalva az emlékeiket felidézô arcokra összpontosított. ${ }^{[16]}$ Bár számos, elsôsorban a sztálinista vezetés búneit taglaló történelmi tabu tematizálódott, Sárközy Réka rámutat, hogy a 80as évek magyar dokumentumfilmjei a „történelmet sorozatos sérelmek történeteként”[17] értelmezték és közvetítették, ami a magyar társadalom önigazolásához és a felelôsség elhárításához vezetett. Ez a történelmi szemléletmód a holokauszt további elhallgatását 
eredményezte az alkotók részérôl, így bár néhány alkotásban megjelent az Endlösung témája, közel sem váltak ezek a filmek olyan jelentôs kulturális eseményekké, mint a Szovjetuniót megszálló magyar hadsereg pusztulását (Krónika. Sára Sándor, 1982) vagy a magyarországi kényszermunkatábort (Recsk. Böszörményi Géza - Gyarmathy Lívia, 1988) leleplezô alkotások.

A szigorú cenzurális felügyelet alatt álló dokumentumfilm-gyártásban tehát a holokausztról szóló alkotások egyike sem tartozott a korszak „támogatott” múvei közé. A három elemzett film mindegyike kis költségvetésből, egyéni kijárás alapján, a bevett mechanizmusok megkerülésével, kísérleti jelleggel készülhetett el. ${ }^{[18]} \mathrm{A}$ három példám közül az Éva A 5116 egy erôsen irányított filmgyártásban, az uralkodó emlékezetpolitikai narratíva részleges érvényesítésével, míg a Kádárkorszak erodálódásának és a cenzurális korlátok enyhülésének idôszakában készült két másik film a köztük eltelt idô függvényében különbözô mértékben, de egyaránt a zsidóságot érintô társadalmi tabuk kimondását és az uralkodó emlékezetpolitikai keretek felrúgását hozta el az államszocialista nyilvánosságba.

\section{Kísértetjárás az Éva A 5116-ben}

Az Éva A 5116 sajátos kulturális és politikai kontextusban született. A holokauszt értelmezése terén ekkor még a progresszív narratíva államszocialista változata az uralkodó paradigma. A progresszív narratíva „azt állítja, hogy a társadalmi gonosz által kiváltott trauma leküzdhetô, hogy a nácizmus le lesz gyốzve és el lesz törölve a föld színérôl, és hogy egy olyan traumatikus múltba lesz végül számúzve, amelynek sötétségét egy új és erôteljes társadalmi fény fogja majd szétoszlatni”. ${ }^{[19]} \mathrm{A}$ progresszív narratíva magyarországi változatában, a szocialista humanizmusban a kommunizmus gyôzi le a mindenkori fasizmust és hoz el egy emberhez méltó életet. A szocialista humanizmus nem vetett számot a holokauszt egyedi, traumatikus tapasztalatával, ami ellentmondott a humanitásra alapozott kultúra fejlôdés- és üdvtörténetének. ${ }^{[20]}$ A szocialista humanizmus univerzális magyarázóelve és esztétikája azáltal szolgálta a Kádár-rendszer politikai-kulturális érdekeit, hogy segített elfelejteni a holokauszt valóságos tényeit és benne a magyar társadalom felelôsségét. ${ }^{[21]}$

Másfelól viszont a film már az Eichmann-per után készült, ami Annette Wieviorka szerint a tanú korának eljövetelét hozta el. ${ }^{[22]}$ A túlélôk személyes tanúságtételei a holokauszt értelmezésének tragikus narratívájához vezetnek ${ }^{[23]}$, ami az államszocializmus idején Magyarországon még nem bontakozhatott ki, ám az Éva A 5116-ban már megjelent. A film nem sokkal az Eichmann-per után készült, ami alapvetôen változtatta meg a holokauszt emlékezetpolitikai kereteit nemcsak Nyugaton, hanem Magyarországon is. „Minden hivatalos ködösítés mellett is az Eichmann-pertôl kell számítanunk a Holocaustról való nyilvános beszéd kezdetét Magyarországon: a zsidógyilkosság emlékének közüggyé válását." ${ }^{[24]}$ A film recepciójában ugyanakkor még világosan tetten érhetố a Kádár-rendszer emlékezetpolitikai keretrendszere, az az Eichmann-perról szóló tudósításokban is követett felfogás, hogy a kritikusok kerülték a zsidó szót, a filmben bemutatott sorsokat a fasizmus áldozataiként írták le, és egy univerzális humanista üzenetet olvastak ki az 
alkotásból, ${ }^{[25]}$ miközben a 60-as évek elején ritkaságszámba menô értô és érzékeny szakkritika rámutatott a filmet átjáró tragikus narratívára. ${ }^{[26]}$

Az Éva A 5116 forgatása a párt országos napilapjában ${ }^{[27]}$ és a zsidó hitközség Új Élet címú hetilapban 1962 decemberében megjelent újságcikk nyomán indult el. A cikk hírt adott Eva Krczrôl, a magyar származású Oświęcimben élô lányról, aki kisgyerekként élte túl az auschwitzi haláltábort, és Magyarországon keresi családját. Erre és a zsidó hetilapban megjelent újságcikkre több százan jelentkeztek olvasói levél formájában. Nádasy László forgatókönyvíró-rendezô az újságcikkek nyomán a Budapest Filmstúdióban kezdi el forgatni a filmet. Az emlékezetpolitikai kényszerek és lehetôségek befolyásolták az Éva A 5116 szerkezetét, ami a múlt és jövő, a holokausztot felnôttként átélt nemzedék és az államszocialista politikai rendszerben szocializálódó fiatalok szembenállására épül. Nádasy László úgy képes a holokauszt traumáját hitelesen reprezentálni, hogy közben a progresszív narratíva elvárásait is kielégíti. A progresszív narratívát a bevezetés magyarázó módjában elhangzó hangkommentár indítja el, amely patetikus hangvételben összefoglalja a megsemmisítô táborok történetét, nem hallgatva el, hogy a transzportok magyarországi zsidókat vittek Auschwitzba. A hangkommentárt a múzeummá alakított auschwitzi koncentrációs táborban készült felvételek, valamint a deportálásokról, a koncentrációs táborokról, a halottak tömegeirôl, a csontsovány túlélőkről készült, sokkoló archív fényképek és filmek kísérik. Az archívokat és az auschwitzi múzeumban tett látogatást ellenpontozza az emberarcú szocializmus boldogságképe. A vidám, az életnek örvendezô fiatalok képsorai azt sugallják, hogy az új generációnak már nem kell Auschwitz árnyával küszködnie.

A címszereplō, Eva Krcz nem önálló személyiség, hanem a film emlékezetpolitikai kettôsségének megfelelôen különbözô szimbolikus jelentéseket hordozó karakter. A holokauszt progresszív értelmezésében Eva a jövôt képviseló tipikus fiatal, aki kirakatokat néz, ruhát próbál, barátnőivel sétál, táncol, élvezi az életet, és szinte semmire sem emlékszik Auschwitz élményébôl. Az auschwitzi múzeum munkatársa, Tadeusz Szymański biztatására Eva mégis megpróbálja megkeresni magyarországi szüleit, s ezzel megfordítja az idô kerekét, elindul vissza a múltba. A szülôkeresés a kollektív amnéziát fenntartó progresszív narratíva széttöréséhez és a trauma örök jelenének felmutatásához vezet. Eva Magyarországra látogatása a holokauszttúlélô különös hazatérése (s mint ilyen, $A$ látogatás elófutára), amelynek során a hazatérô áldozat semmire sem emlékszik múltjából, állandóan változó vendéglátói, lehetséges rokonai próbálnak emlékeket kölcsönözni neki. Evának a hazatérése során nem egyetlen valóságos, elveszett múltat kell elgyászolnia (mint Bruck Edithnek A látogatásban), hanem számtalan lehetséges gyerekkor, szülő és rokon elvesztését kell megélnie. Eva alapvetôen nem önmaga elvesztett gyerekkorát, hanem „szülei”, megannyi Auschwitzban gyerekét elvesztett apa és anya, valamint gyerekeik, számtalan kis Éva sorsát siratja. Eva találkozásai a holokauszt túlélóivel felszakítják a holokausztot felnôtt fejjel megélt generáció fájdalmas emlékeit, ami a lányt azzal a rá nehezedô megoldhatatlan feladattal szembesíti, hogy neki kellene helyreállítania Auschwitz összes áldozatának visszahozhatatlan veszteségét. A találkozások során megindult, könnyekre fakadó Eva ezáltal az egész közösséget érintố gyász megélőjévé, s ezáltal a nézô érzelmeinek kanalizálójává válik a 
filmben.

Az Éva A 5116-ban nemcsak a túlélôk, de a rokonaik és a szomszédaik is a holokauszt traumájának hatása alatt állnak, hiszen, mint Dominick LaCapra figyelmeztet rá, a traumatikus esemény „mindenkit megérint, aki kapcsolatba kerül vele: elkövetôt, kollaboránst, járókelôt, ellenállót s azokat is, akik utána születtek”. ${ }^{[28]}$ A magyarországi deportálások után húsz évvel elszenvedôi még nem dolgozták fel a traumát, különösen nem egy olyan társadalomban, amely a múltbéli szenvedés elhallgatására kényszeríti az áldozatokat. A dokumentumfilm készítése a trauma elszenvedôi számára megnyitja a lehetôséget, hogy legálisan beszéljenek múltjukról és fájdalmaikról a nyilvánosság elôtt. A film úttörô technikájának döntô szerep jut a szereplôk arcának és hangjának egyenértékú visszaadásában. A korabeli magyar filmgyártásban még nem állt rendelkezésre a direct cinema és a cinema verité új vívmánya, a könnyú, 16 mm-es, szinkronhang rögzítésére alkalmas kamera, ezért a képet és a hangot külön rögzítették. A magyar dokumentumfilm-történetben a mindentudó narrátorhangra épító magyarázó vagy a képek erejére építố lírai dokumentumfilmek után forradalmi újdonságot képviselô Éva A 5116 a tanúságtevôk hangjának visszatérését hozza, ahogy Shoshana Felman fogalmaz a Shoah kapcsán. ${ }^{[29]}$ Lanzmann-nal szemben azonban a film készítôi nem kényszerítik - egyfajta morális kötelességre hivatkozva - tanúskodásra a túlélóket, hanem hagyják, hogy a múlt árnyával találkozva érzelmeik felszínre törjenek.

Eva Krcz alakjával a múlt tör be a tabukkal és hallgatással körbevett jelenbe, és segít hangot adni a két évtizede kibeszéletlen fájdalmaknak, a gyásznak és az elfojtott bûntudatnak. Eva a túlélók számára a múlt kísértete, aki visszatér hozzájuk és elevenné teszi számukra a traumatikus emlékeket. Az áldozatok - az elemzésre kerülô késôbbi filmekkel szemben - nem szándékosan térnek vissza a múltba, hanem Eva üt rajtuk Auschwitz reprezentánsaként, ezért a múlttal való találkozás megélése részükrôl sem tudatos és kontrollált. A túlélók az elvesztett kislánnyal kapcsolatos emlékeiket idézve hoznak felszínre valamennyit traumatikus élményeikbôl: hogyan éltek együtt családjukkal a deportálások elôtt, hogyan vesztették el (vagy szem elôl) óket a deportálások során, Auschwitzban, vagy amíg ôk munkaszolgálatban voltak, s hogyan reménykedtek a megtalálásukban. A megszólalások - részben a vágás sajátosságai miatt - sokkal inkább tûnnek szaggatott emléktöredékeknek, a veszteségélmény legfájdalmasabb mozzanatait összesû́rítô képekhez való fixációknak, mint a történteket rendezetten elmesélô, összefüggố narratíváknak. Az Éva A 5116 a tudatos szembenézés helyett a tudattalan helyreállítási vágyak kétségbeesett megélését reprezentálja. Az emlékek szaggatottan feltörô felidézése minduntalan racionalizáló jellegú, ám mélyen irracionális magyarázatokba torkollik azzal kapcsolatosan, hogyan sikerült saját vagy ismerôsük elveszett kislányának megmenekülnie a biztos halálból. „Nem bírom ezeket a dolgokat elfelejteni, elôttem vannak, hiába, nem tehetek róla. Nem tudom, mi lesz velem, ha nem az enyém" - mondja az Elemér nevú egykori munkaszolgálatos túlélô. A megtört arcú férfi mondatai összesúrítik magukban a trauma kísértô élményeit, a felejtésnek az államszocialista emlékezetpolitika által rárótt imperatívuszát, végül pedig az Eva által felkínált konkrét jóvátételi lehetôséget, amely a veszteség megszüntetésének, következésképpen a 
kényszeres emlékezésnek felfüggesztésével kecsegtet.

A pszichoanalitikus traumaelméletek flashbackek, álmok, a múlt különbözó nem narratív betörései mentén a trauma elmesélhetetlen, megragadhatatlan, reprezentálhatatlan jellegére mutatnak rá. „A flashback vagy a traumatikus újrajátszás egyszerre hordozza az esemény igazságát és az esemény felfoghatatlanságának igazságát." ${ }^{[30]}$ A traumatikus élmények közelségének köszönhetôen az Éva A 5116-ban még a történtekrôl alkotott összefüggố narratíva és a fájdalom kimondásának helyét idônként az álmok elmesélése veszi át. Az egyik megszólaló, egy holokauszttúléló arról beszél, hogy az elpusztított feleségével gyakran álmodik, ám kislányával sohasem. A kislány halálának élménye még a feleségéénél is erôsebb cenzúra alá esik a túlélô tudati múködésében, közvetlen formában nem engedi az álomtartalomban megjelenni. A másik szereplő, egy egyenruhás férfi megszólalása álma felidézésével kezdôdik, amelyben az ô saját „Évája”, vagyis saját holokausztban elvesztett kislány ismerôse elevenedik meg.

Azt álmodtam, hogy valahogy be voltam csukva, egy gettófélébe zárva, és ott mentünk a többivel együtt. És egy nô volt az ôr, és mondom neki, hogy legyen szíves, kartársnő, engem ne tessék ittfogni. Ne fogjon itt, én a falubeliekkel akarok menni. És hát aztán jobban nézem, és megismertem ezt a kislányt. Hát mondom, te vagy az Évike! Hát maga, Gyuri bátyám, maga már sehova sem megy. De mondom, hogy én akkor is elmegyek az én barátaimmal.

A rendezố a zsidók gettóba terelésének és bevagonírozásának archív képsoraival illusztrálja az álom történetét. Az álom értelmezéséhez csak ezután kap a néző fogódzókat. A férfi - akit ekkor már megmutat a kamera - elmeséli, hogy a holokauszt idôszakában tanítóként dolgozott egy falusi iskolában, és egy zsidó kislány, akinek már nem volt szabad óvodába sem mennie, rendszeresen bejárt az óráira. Egy alkalommal, amikor a plébános elment az ablak elôtt, a tanító félelmében „demonstrációs eszközként” állította be a kislányt, azt mondta neki, hogy rajta keresztül illusztrálja a diákoknak, milyenek a zsidók. Bár az interjúrészletben nem hangzik el, sejthetô, hogy álma új keletû és az Eva Krcz-rôl olvasott újsághír idézhette elô. A volt tanító álmát a - Judith Hermann-i kifejezéssel élve - „szemtanú-búntudat”[31], a felnôttként visszatérô áldozattal való találkozást övező fantázia motiválta. Gettóba zártsága az áldozatokkal való azonosulásként értelmezhetô. Az álom elmesélésében árulkodóak az elhagyott alanyok: a férfi nem mondja ki, hogy kikkel volt összezárva és kikkel szeretett volna együtt menni - a zsidó szó közéleti tabusítása és a tudat cenzúrája figyelhetố meg a beszámolóban. Az álom másik fontos mozzanata a bûntudatból eredô megfordítás. Egykoron „Gyuri bácsi” volt az „ôr” a gettóban, vagyis tanítóként azzal a gesztusával, hogy demonstrációs állatként címkézte fel s így rekesztette ki „Évát” az emberi közösségből, míg a kísérteties módon felnôttként visszatérô halott a felette hatalommal rendelkezô ốr szerepét kapja álmában, aki nem engedi, hogy a „barátaival”, feltételezhetôen zsidó sorstársaival tartson a deportálásokban, hogy utólag osztozzon sorsukban. A bûntudatról nyíltan árulkodó álom érzelmi motivációját aláhúzza, hogy a férfi zavartan elismeri, ô maga is felelôsnek érzi magát a zsidók elpusztításának bûnében, még ha akkoriban nem is volt 
tudatában a történeteknek. ${ }^{[32]}$ A múltbéli tehetetlenségét, búnrészességét kompenzálandó szeretné az életbe visszavarázsolni „Évikét”, jóvátenni a bûnnel terhes múltat. A megszólalás jelentôségét az adja, hogy ez az egyetlen általam ismert vallomás a magyar dokumentumfilm-történetben, amelyben a nem zsidó szomszéd/szemtanú a holokauszt során elpusztított magyar zsidó embertársaival kapcsolatos, mélyen átélt bûntudatát osztja meg a nyilvánossággal a kamera elôtt.

A vallomásokat Eva Krcz újságcikkben közölt gyerekkori fotója indítja el, ezért a film fô motívuma a fotó, az arckép. A kép a szinkronhang hiánya miatt önálló minőséget alkot, Sára Sándor operatôr szabadon komponálhatott, nem kellett szükségképpen a beszélô arcot követnie kamerájával. Sára a 60-as évek magyar fotó-, valamint játék- és dokumentumfilm-múvészetében egyedi minôségú portrékkal túnt ki, 1962-ben bemutatott Cigányok címú költôii dokumentumfilmje a magyar dokumentumfilm-múvészet egyik fordulópontját jelentette. Sára az Éva A 5116-ban többnyire nem beszéd közben fényképezi az arcokat, tehát vizuális szempontból nem a tanúskodás pillanata a legfontosabb mozzanat, hanem a megtört tekintetekből kiolvasható szótlan fájdalom, a túlélôket gyötrô melankólia, a poszttraumás állapot. A progresszív narratívánál hatásosabb filmes eszközök ezek az arcképek, amelyek a múlt töredékesen felidézett emlékeinél is erôteljesebben árulkodnak a holokauszt traumatikus természetérôl.
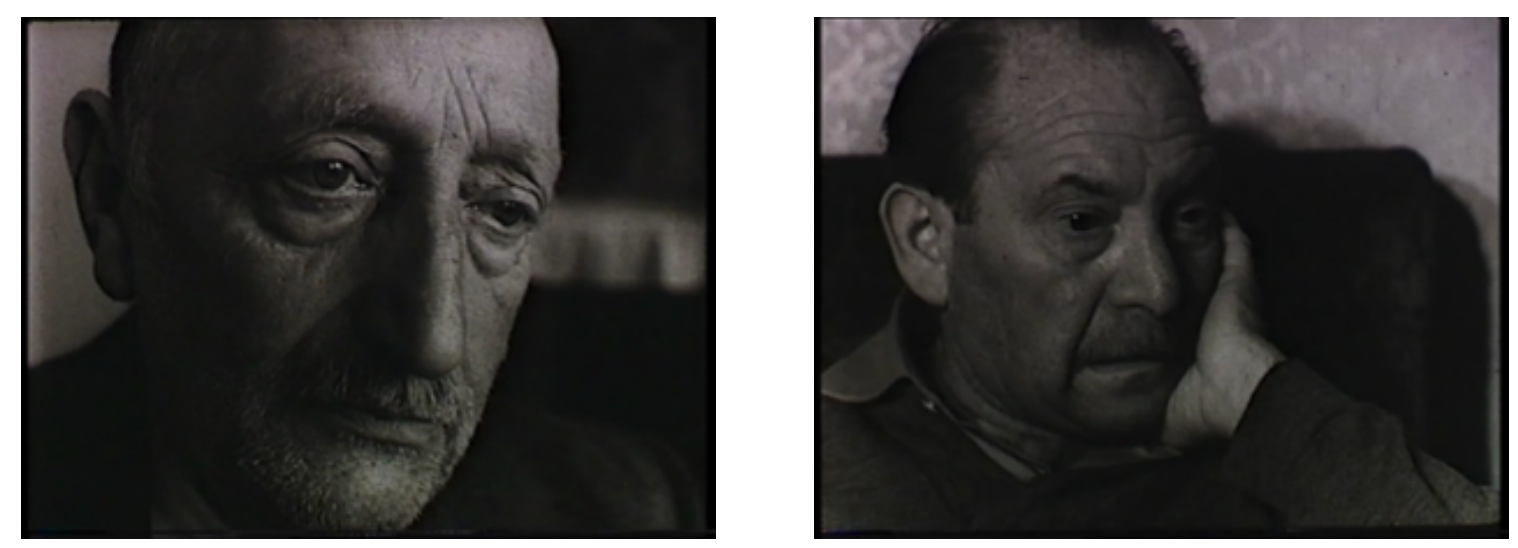

Evva A 5116

A jóvátétel kínzó vágya a hasonlóságok kitartó keresésére sarkallja az emlékezôket. Eva a projektív felület, amelyre minden túlélô, szomszéd rávetítheti helyreállítási vágyát és bûntudatát. $\mathrm{Az}$ auschwitzi tábor felszabadulása után készült gyerekkori fotóját az elpusztított kislányok korabeli fotóihoz méregetik, a test vonásaiban, a gesztusokban keresik és találják meg a hasonlatosságot vagy a gyerekkel vagy annak szüleivel. A fotó nézegetésével saját gyerekükké igyekeznek tenni Evát, ami a túlélést jelenti számukra. A fénykép kisajátításával egyúttal arcot próbálnak adni a halottaknak és elvesztetteknek. A traumaelméletben fontos szerepet kap az arcadás, a prozopopeia, ami „egyfajta etikai dimenzióra tesz szert, részben Lévinas filozófiájának köszönhetően, aki az 
etikai filozófiát megalapozó másik alapvetô másságát az arc figurájával írta le. A prozopopeia tehát a felépülés (recuperation) stratégiájává válik, amely visszaszerzi a másikat a felejtés homályából”[33] . Az Éva A 5116 szereplói az elvesztett arcokat igyekeznek elóhívni a kollektív amnéziából, míg a film alkotói a szenvedô arcok megmutatásával a holokauszt traumájának elfelejtésére kárhoztatott áldozatokat hozzák a nyilvánosság napvilágára.
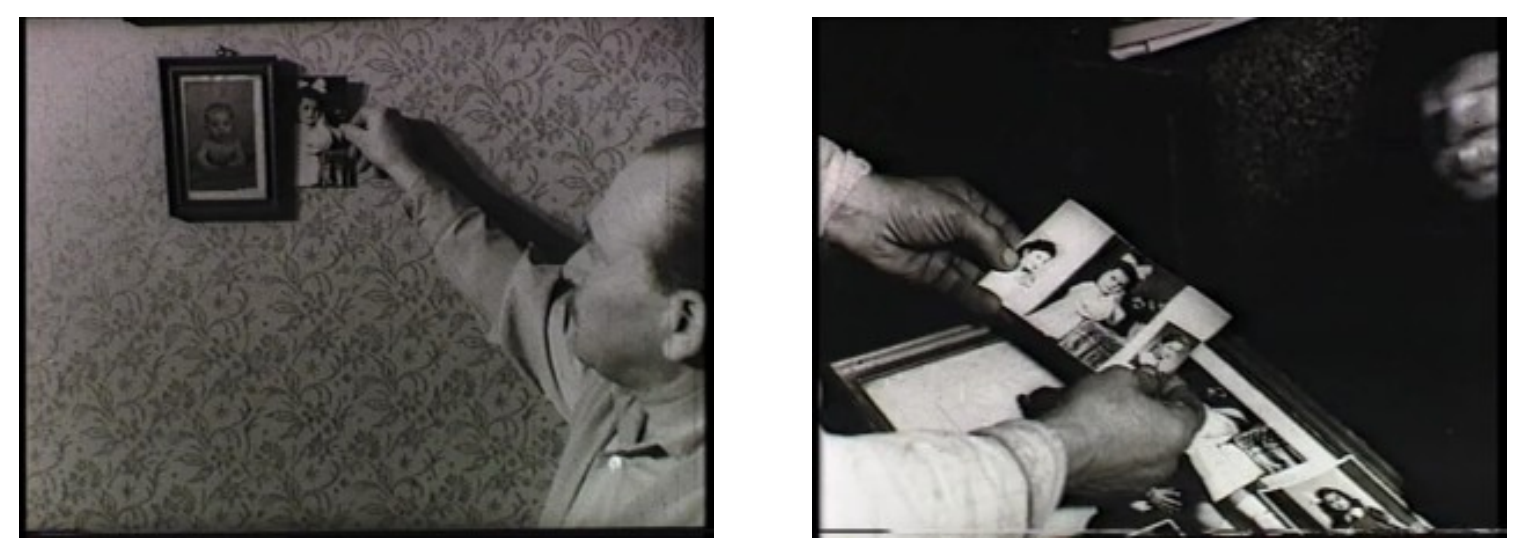

Evva $A 5116$

A filmkészítôk egy különös vizuális megoldással húzzák alá a halálból visszatérô lány kísértetiességét. A búntudattól szenvedó tanár visszaemlékezése közben a fotókkal teleszórt asztal polírozott felületén az emlékező férfi és egy masnis kislány tükröződik. A képsor azt sugallja, hogy az elvesztett, feltehetôen meggyilkolt zsidó kislány kísértetként tovább él a túlélók és szemtanúk tudattalanjában. A következô képsorok a masnis kislányt szemtôl szembe mutatják, aki valószínûsíthetôen a férfi saját kislánya, a vágás mégis azt sugallja, hogy az újságban közölt fotón látott egykori kislány elevenedett meg. A szekvencia Eva és az elvesztett kislányok egyformaságára mutat rá, amit a hajukba kötött szalag húz alá. Az emlékezôk nagy részéből a hajba kötött szalag hívja elố az emléket, nem a konkrét gyereket látják maguk elôtt, hanem az Ártatlan Kislány archetípusát, akinek tudatukba való betörése kanalizálja a túlélók gyászát és búntudatát.

Eva látogatásával a túlélốk számára ténylegesen megelevenedik a fotókon látott arc, és visszatér az életükbe. Megérintik az arcát, és a tapintás segítségével igazolják a testté lett kép azonosságát az elvesztett gyerekkel. A hús-vér Evával nem beszélgetni akarnak, a lány nem válik önálló személyiséggé számukra, hanem a jóvátételi vágyak projektív felülete marad. A tudományos módszer, az ujjlenyomatok elemzése ismét csak a felületek hasonlóságán alapulva adhatna végsô bizonyosságot a rokonságról, amit nem ad meg a csodákra várakozóknak. Az orvosi vizsgálatok negatív leletei azonban nem cáfolhatják meg a halott feltámadásába vetett hitet, és a megszólalók szerint Eva a bizonyítékok ellenére is az ô lányuk, akit másodszorra nem veszíthetnek el. Különös módon rímel erre a Saul fia (Nemes Jeles László, 2015) „címszereplójének” kísérteties története, 
amelyet Georges Didi-Huberman az újrakezdés lehetséges mozzanataként olvas. „Saul példaértéke - és amióta ez a történet létezik, a filmé - azon alapul, hogy egy olyan, a világgal és a benne múködô kegyetlenséggel minden ízében szembeforduló helyzetet tudott teremteni, amelyben létezik egy gyermek, pedig már halott."[34]
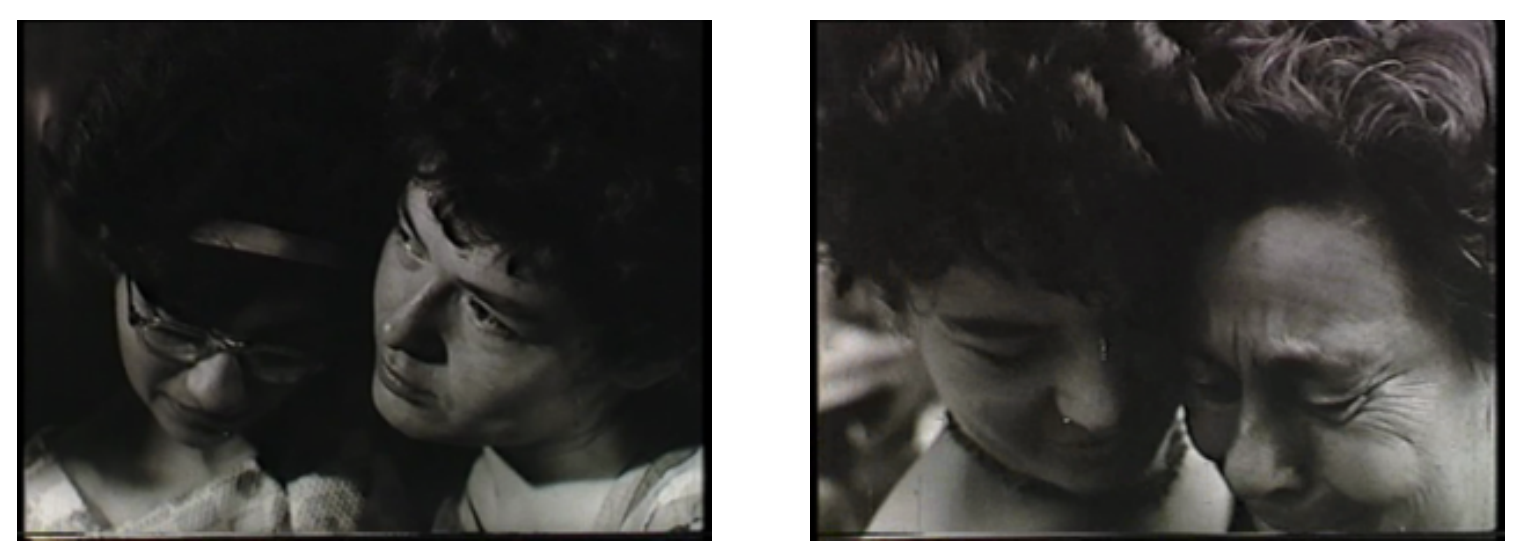

Éva A 5116

A gyermeküket elvesztett holokauszttúlélók és hozzátartozóik jóvá szeretnék tenni a történteket. A valóságos jóvátétel a holokauszt esetében azért sem lehetséges, mert - mint Pintér Judit Nóra írja - nincs egyetlen személy vagy egy jól körülhatárolható csoport, akitôl jóvátételt lehetne várni. Pintér arra figyelmeztet, hogy a jóvátétel valóságosan, a maga konkrétságában nem, csakis szimbolikusan, a trauma feldolgozásával lehetséges. „A jóvátétel materiális értelemben természetesen nem lehetséges. Nem lehet visszafordítani az idôt és meg nem történtté tenni a múlt eseményeit." ${ }^{[35]} \mathrm{Az}$ Éva A 5116-ban mégis felmerül a valóságos, materiális jóvátétel lehetôsége. Az áldozatok traumatikus veszteségét és a szemtanúk búntudatát enyhítheti az auschwitzi halott lány visszatérése. A motívum Simon Srebnik Chelmnóba történô visszatérésének mozzanatát idézi fel a Shoah-ból, amelynek Shoshana Felman értelmezésében megváltó üzenete van. ${ }^{[36]}$ Eva látogatása azonban nem válik megváltó mozzanattá egyetlen túlélô számára sem, csupán felszínre hozza az elfelejteni vágyott traumatikus tapasztalatot, ám Auschwitzba történô hazatérésével nyitva hagyja a feltépett sebet. A pszichoanalitikus traumaelmélet által javasolt terápiára, a tanúságtételre, az élmények tanúk elốti feldolgozására, ami Dori Laub szerint „inherens módon a veszteséggel való szembenézés folyamata”[37], a magyar dokumentumfilmben még két évtizedet várni kell.

\section{Otthonkeresés $A$ látogatásban}

A látogatás Bruck Edith, Olaszországban éló írónô játékfilmtervének werkfilmjeként indult. A Filmfőigazgatóság a benne megjelenô népi antiszemitizmus miatt magyarellenesnek minôsítette 
Bruck Edit forgatókönyvét és nem engedélyezte a forgatást. A játékfilmhez tervezett werkfilm rendezôje, B. Révész László rábeszélte a Budapest Filmstúdió vezetôjét, Nemeskürty Istvánt, hogy

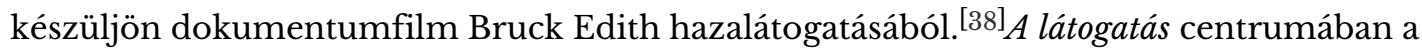
fốszereplô szülőfalujába történô visszatérése áll, azonban kultúrpolitikai okok miatt a magyar társadalmat önvizsgálatra kényszerítô aktust a rendezônek a portréfilm múfajába kellett csomagolnia. A film ezért elóbb hagyományos interjúk segítségével bemutatja Bruck Edith olaszországi életét, írói munkásságát, csak utána követi végig a magyarországi utazást a direct cinema megfigyelố technikáival. A filmet 1982. december 2-án mutatták be a magyar moziban, és a korabeli viszonyok között kevés vetítést és alacsony nézôszámot ért el ${ }^{[39]}$, de mivel a Magyar Televízióban koprodukcióban készült, később a televízió is vetítette, így feltételezhetôen sok emberhez juthatott el. A kritikák a hatvanas évekhez képest nyíltabban beszélnek zsidóságról, rasszizmusról, antiszemitizmusról, ugyanakkor az egyik országos napilap kritikusa a fószereplôt bírálja amiatt, hogy fel meri hánytorgatni zsidóként elszenvedett sérelmeit. ${ }^{[40]}$

A hazalátogatás motivációja kettôs: van egy kimondott, racionális és egy kimond(hat)atlan, tudattalan célja. A deklarált cél a megbékélés. A film fôszereplőjét 1944-ben deportálták szülőfalujából, az északkelet-magyarországi Tiszakarádról. A koncentrációs táborból szabadulva elôször 1945-ben tért vissza a faluba, ahol a kifosztott, összeszemetelt, összerondított házukat kellett viszontlátnia, s ahonnan lényegében elüldözték ôt a falubeliek. ${ }^{[41]}$ A második látogatás 1962 ben történt, amikor már sikeres pályakezdô olasz írónôként, Illyés Gyula olasz fordítójaként tért haza Tiszakarádra, s még akkor is ellenségesen, apja állítólagos tartozását a jómódú emigránson visszakövetelve fogadták egykori szomszédai. Bruck Edith a kamera elôtt deklarálja a deportálás utáni harmadik, 1981-es hazatérésének célját: meg akar békülni az országgal és önmagával, ki akar engesztelődni, hogy megszabadulhasson a trauma gyötrô fájdalmától. 
A hazatérésnek ugyanakkor minden bizonnyal van egy tudattalan, nem racionalizálható célja is. A nosztalgia úzi-hajtja vissza az otthonától, gyerekkorától megfosztott holokauszttúlélôt, szeretné újra megtalálni elveszett otthonát, gyerekkorát. Elie Wiesel 1964-ben tért vissza szülôvárosába, Máramarosszigetre, s a látogatás kapcsán írott, The last return címú esszéjében a következôképpen fogalmaz az utazással kapcsolatos érzéseirôl: „A város egyszerre vonzott és riasztott engem. Látni akartam és nem akartam látni." ${ }^{[42]}$ Az ellentmondásos kettốsség, a vonzódás és a rettegés a gyermekkor elveszett világa iránt járja át Wiesel egész esszéjét, amelynek konklúziója, hogyutazása végsô soron a „semmibe vezetett”, mert a hely „sohasem létezett - ez a város, amelyegykor az enyém volt”. ${ }^{[43]}$ Wiesel a nosztalgia által megképzett gyermekkori világot, „a várost,amely egykor övé volt" látja szertefoszlani a hazautazás tapasztalatának éles fényében. Aszülővárosa sohasem volt, vagyis sohasem volt olyan, mint amilyennek a traumatikus élménytkompenzáló nosztalgia emlékezetében láttatta vele. Bruck Edith hiába tért haza már kétszer isszülöfalujába, a fájdalmas közvetlen tapasztalatok sem semmisítették meg benne a gyermekkoriránti nosztalgiát. A látogatás fôszereplöje ekként a harmadik hazautazásakor is még Wieselesszéjének konklúziója eloott áll, s a film éppen azt ábrázolja, hogyan juttatja el ôt a The last returnkonklúziójáig ez a kamera elôtt lezajlott visszatérés. 
Az elszenvedett trauma miatt vágyott jóvátétel az Évában látott konkrét fizikai feltámadás helyett szimbolikus síkra terelődik, ami az elveszett otthont, családot és hazát jelképezô ház motívumában összpontosul. A film érzelmi csomópontja a fôszereplô két, egyformán otthontalan háza: az egyik, egy hatalmas olaszországi tengerparti ház hiába várja a kiirtott családját, míg a másik, a gyermekkori ház összeomlóban van. Bruck Edith elmondja, hogy tengerparti nyaralójukat eredetileg kicsinek tervezték férjével, de ô egyre nagyobbra építtette és egyre több földet akart köré szerezni magának. A főszereplő tudattalanul az egész családjának építtette a házát, ám amikor a ház kész lett, túl nagynak és üresnek érezte, mert nem tudta megtölteni családdal, gyerekekkel. A családja és otthona elvesztésének traumájáért magának kikövetelt szimbolikus jóvátétel anyagi és érzelmi értelemben is szükségképpen kudarcot jelentett. A régi családi ház meglátogatása szintén egy tudattalan jóvátételi igényt szolgál, amellyel a holokauszt traumatikus élménye elôtti idôbe szeretne visszatérni. A nosztalgikus élmény helyett a traumatikus élmény visszatérése várja, az egykori szülőház összeomlása, a képzeletben még létezô otthon végleges és visszafordíthatatlan elvesztése. Bár az írónô az egész utazás során higgadt, reflektív módon beszél a múltról, amikor hazatérve falujába meglátja a félig összedôlt családi házukat, hangosan zokogni kezd, és érzelmileg összeomlik. Bebarangolja az összeomlott tetejú, szeméttel összedobált házat, benéz az ablakon és markolja a vályogot, amelyet egykor ô és családtagjai vetettek saját kezükkel. A fốszereplô itt szembesül azzal, hogy földdé válik alkotásuk, fizikailag sem marad semmi utánuk, a gyermekkora és családja utolsó fizikai nyoma is eltûnik a szülőföldjérôl, ami így végleg megszúnik otthonnak lenni. Az utolsó emléknyom az a kopott lábas, amit az egyik szomszédasszony visszaküld neki, ahelyett, hogy engesztelés gyanánt ô maga hozná el személyesen az egykor Bruck családjától ellopott tárgyat.
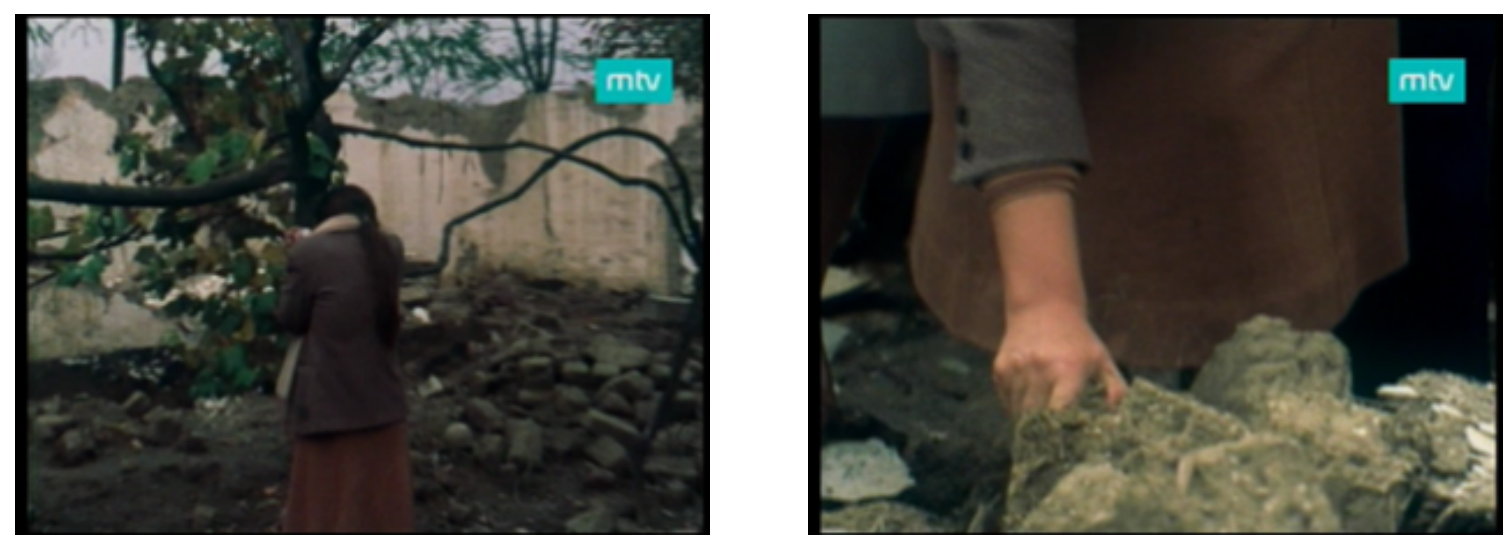

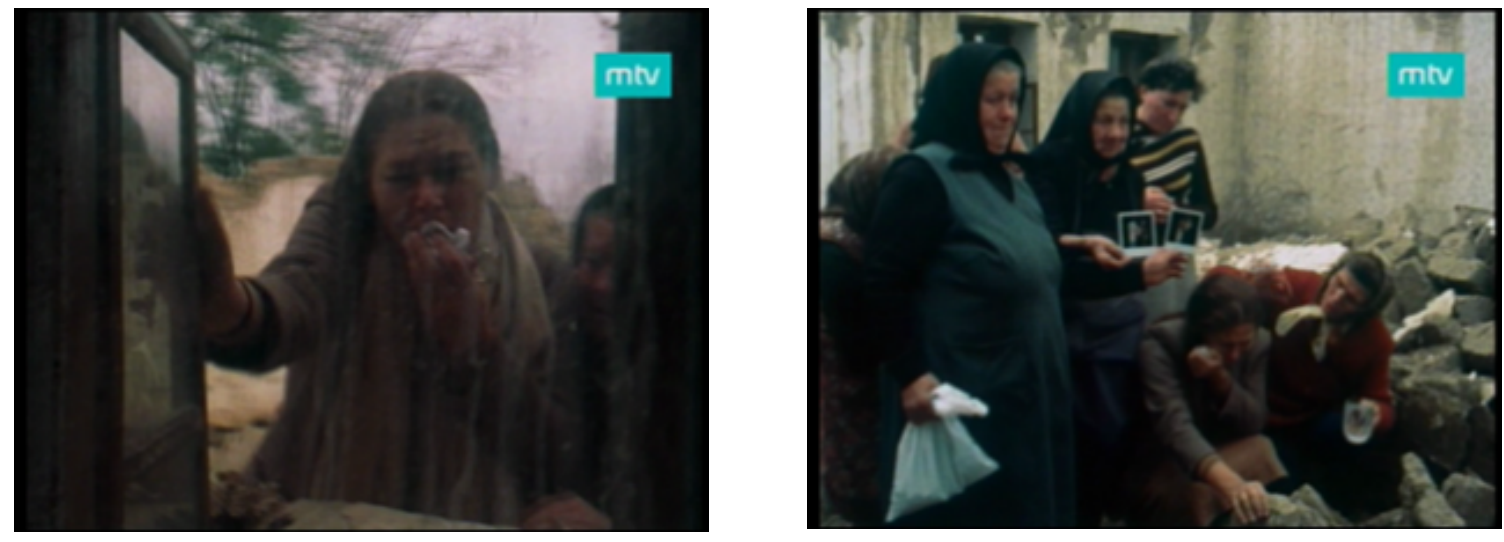

\section{A látogatás}

A filmkészítő vizuálisan is aláhúzza a ház érzelmileg terhelt motívumát. Elôször az olaszországi tengerparti nyaraló esetében él a montázs eszközével, amikor a házról egyre távolabbi képeket vág ritmikusan egymásra. Másodszor a főszereplő szülóházához érkezésekor a jó állapotban lévő házról 1962-ben készült felvételek és az összeomlott ház jelenkori képének gyorsmontázsával a főszereplóben lejátszódó érzelmi sokkot imitálja. Végül a ház pusztulását is érzelmileg hatásos montázzsal húzza alá: egy zsidó siratódal alatt az elhanyagolt zsidó temetó sírjait, a házat belülrôl és a ház lerombolását felülnézetből komponálja össze az eltúnés montázsává.

Bruck képzeletben még létezó otthonának eltúnését látva kénytelen végérvényesen szembesülni otthontalanságával. A nosztalgia úzte vissza gyerekkora helyszínére, ám a traumatikus tapasztalat végérvényesen elpusztította a nosztalgia világát. A holokauszt túlélójének ezt az otthontalanságát fogalmazta meg Jean Améry Mennyi haza kell egy embernek? címú esszéjében. Bruck otthontalansága ellen küzdve hiába tér vissza gyerekkora helyszínére, nem azt találja meg, amit keresett, mert mint Améry írja - „nincsen visszaút, mert egy adott helyre való újbóli belépéssel sosem kaphatjuk vissza az elvesztett időt". ${ }^{[44]}$ Améry felidézi a népdalokat, meséket, illatokat, képeket, amelyek az emberben a szülőföldet idézik fel, s amelyeknek „édességétől” minden racionalizálási törekvése ellenére élete végéig nem tud szabadulni. Bruck tökéletesen illusztrálja Améry állításait, többször is beszél a film során a tiszakarádi gyerekkor konkrét, materiális élményeirôl, és az ott tanult dalokat énekli. Az írónő hármas - magyar, zsidó, olasz - identitásában saját szétszaggatottságát érzékeli, ám egyikrôl sem hajlandó lemondani. Magyar zsidó identitásában döntő szerepet játszanak gyermekkori anyagi élményei, zeneisége, érzéki benyomásai, ugyanakkor ez a gyermekkori világ örökre elveszett, kivetette ôt magából. „A haza ott van, ahol gyermekkorunkat és ifjúságunkat töltöttük. Aki elveszítette, elveszett marad.”[45] Bruck hármas identitásában két haza magáénak vallásával kísérletezik, ám a hazát egyetlen térbe súrítô otthon megtartásával, felépítésével kudarcot vall, s e tekintetben sorsa Améry állítását és sorsát visszhangozza.

A jóvátételi fantázia tudattalan vagy tudatos, de bevallatlan céljának kudarca után lássuk, hogyan valósul meg a főszereplő látogatásának deklarált célja! Bruck Edith látogatása során a kisközösség, 
tágabban az egész magyar társadalom kollektív amnéziájával szembesül. A családi ház lerombolása, a zsinagóga eltûnése és a zsidó temetố elhanyagolása konkrét fizikai jelei annak a kollektív amnéziának, ami a holokausztot illetően a felelősséget hárító magyar társadalmat áthatja. A tárgyi emlékek eltüntetése a deportálásokban való néma asszisztálásnak, a zsidó házak kirablásának és a visszatérô kiüldözésének folytatása. A falusiak, akik egykor némán végignézték a zsidók elhurcolását, kifosztották házaikat, megfenyegették, amikor a fôszereplô visszatért a haláltáborból, második visszatérésekor apja állítólagos tartozását követelték rajta, ezúttal vendégszeretôen és együttérzően fogadják az asszonyt, együtt sírnak vele és közösen vigasztalják ôt. A családi ház számukra is mélyen átélhetô és könnyen interpretálható pusztulásában (a gyökerek, a család, az otthon veszett el) együtt éreznek vele, ám nem sok empátiát mutatnak a specifikusan zsidó identitásához kapcsolódó fájdalmával szemben. Ne sírjon, más is sokat szenvedett, mondják a zokogó fôszereplőnek. Amikor pedig a zsidósággal szemben próbál az egyik volt falusi osztálytárs szolidaritását kifejezni, akkor is a fajgyúlölet számára kézre álló retorikájához fordul. A cigányokkal kellett volna kezdeni a népirtást és nem „veletek”, vagyis nem a zsidókkal, mondja a férfi a maga naivitásában árulva el, hogyan konstruálja meg a többségi magyar társadalom a mindenkori eltávolítandó Másikat saját közösségi identitása érdekében. A film tabudöntô módon rámutat, hogy az elôítéletesség, a rasszizmus lappangva tovább él a többségi magyar társadalomban, csak ezúttal nem a kiirtott, elúzött zsidók, hanem a romák a célpontjai. ${ }^{[46]}$

A falusiak közül bưntudatról vagy a múlttal kapcsolatos felelősségrôl senki nem beszél. Az egyetlen bûntudatról árulkodó mozzanat, hogy az egyik szomszédasszony egy kopott lábast küld Bruck Edithnek, amelyet a deportálások után hátrahagyott családi házból lophatott el. A kiengesztelés gesztusa ismét félrecsúszik, mert ahelyett, hogy ő maga hozná el személyesen egykori szomszédjának, sértô módon egy közvetítôre bízza az emlék visszajuttatását. Szimbolikus módon mégiscsak ez a koszos, elhasznált lábas maradt tárgyi emlék gyanánt a fôszereplô múltjából. A kollektív felejtés vágya túllép a hátrahagyott zsidó vagyontárgyak szétlopása miatt búntudattól terhelt falusi közösségen. Az államszocialista kultúrpolitika emblematikus írója, Illyés Gyula azt tanácsolja az ôt meglátogató fốszereplônek, nem mellékesen fordítójának és barátjának, hogy ápolja büszkén a magyar és olasz identitását, ám zsidóságát próbálja meg elfelejteni. ${ }^{[47]}$ Bruck Edith hevesen ellentmond Illyésnek („Te így látod, de én másként érzek”), mire a férfi vita helyett azonnal másra tereli a szót, és a régi, közös fotókat emlegeti.

Bruck Edit a magyar társadalom közönyére, felejtésére, bujkáló rasszizmusára a tudatosítás és emlékeztetés értelmiségi válaszát adja. Vitatkozik Illyéssel, aki burkoltan a holokauszt elfelejtésére és a zsidó identitás megtagadására buzdít. Visszautasítja az egykori osztálytárs félrecsúszott szolidaritását és elítéli a rasszizmust, bárki ellen irányuljon is. Az emlékezés szükségessége végett órát tart a holokausztról a helyi iskolásoknak, ám a gyerekek semmit sem tudnak már a negyven évvel korábban ott élt zsidóságról, és a többségi magyar társadalom önfelmentô vágyfantáziáinak megfelelố narratívát adnak a holokausztról (a németek vitték el a gazdag zsidókat). 
Bruck Edith végül is mindezen ellentmondásos tapasztalatok ellenére ragaszkodik eredeti céljához. Otthontalansága, kifosztottsága és megnemértettsége tudatában békél meg a falusiakkal. Sorra megöleli sírva egykori szomszédait, osztálytársait és az idôsebb asszonyokat. A holokauszttúlélônek sikerül felülkerekednie haragján, hogy végre négy évtized után megbékéljen önmagával. „A jóvátétel [...] nem a múltat teszi jóvá, hanem a múlthoz való viszonyomat. A jó emlékezésnek így terápiás funkciója van, ez maga a jóvátétel lehetôsége."[48] Bruck Edith hazautazása egyfelôl a nosztalgia vágyfantáziája által diktált otthonteremtési kísérletként kudarcot vallott, másfelól viszont a traumatikus emlék tudatos feldolgozása a tudatos, kollektív felejtés kollektív emlékezetté formálásaként - a rendezônek, B. Révész Lászlónak is köszönhetően - sikerrel járt.

\section{A Társasutazás mint zarándoklat}

A Társasutazás a játékfilmgyártásra szakosodott Objektív Filmstúdióban készült kísérleti keretból. A film rendezôje, Gazdag Gyula figyelmét egy auschwitzi társasutazás újsághirdetése keltette fel, ezt az ötletét nyújtotta be a filmstúdióba, ám az ötlet nem ment át a szokásos döntéshozatali mechanizmuson, a stúdióvezetô döntött róla. A forgatás és az elfogadás zökkenômentes, ugyanakkor az antiszemitizmustól való félelem miatt akadnak kisebb bonyodalmak a film bemutatása körül. A filmet 1985 februárjában mutatták be a magyar mozik, és dokumentumfilmként viszonylag magas nézôszámot ért el. ${ }^{[49]}$ A kritika egyöntetûen magasztalta a filmet, a korábban tabunak számító kifejezésekkel élve zsidóságról, népirtásról beszélnek a korabeli kritikusok az országos napilapokban is. ${ }^{[50]}$

A Társasutazást a korábbi holokauszt-dokumentumfilmekkel szemben egyáltalán nem kötik az államszocialista kultúrpolitika kényszerei, felrúgja mindazokat a tabukat, amelyeket a Kádárrendszer a zsidósággal szemben kialakított. A film szereplői bátran beszélnek zsidó identitásról, a vallásgyakorlat visszaszorulásáról és a zsidó közösségek eltûnésérôl. Az utazás résztvevôi egyértelmúen a zsidósághoz kötik Auschwitzot, ami korábban „a fasizmus fenyegetésére való közös emlékezés központi helyszínévé vált a kelet-európai szovjet blokk számára, ahol az áldozatok többségének zsidó mivolta marginalizálódott”. ${ }^{[51]}$ A legnagyobb tabutörés mégis az, amikor a megszólalók kimondják, hogy az antiszemitizmus az államszocializmus dacára a jelenben is tovább él. A magyar dokumentumfilm-történetben elôször a Társasutazásban mesélik el részletesen, a személyes visszaemlékezéseken keresztül a deportálások történetét. Másfelôl viszont a szituációs dokumentumfilmezés hatvanas évek végi úttörôje, Gazdag Gyula a korszak magyar történelmi dokumentumfilmjeihez (Pócspetri, Krónika, Törvénysértés nélkül [Gulyás Gyula, Gulyás János, 1988], Recsk) és a tanú korának alkotásaihoz (Shoah) képest kevesebbet él az interjú eszközével, inkább szituációkat visz filmre a direct cinema technikájával.

A film kettôs szerkezetû: a társasutazás szituatív megörökítését refrénszerúen kíséri egy félhomályban beszélô nố visszaemlékezése, aki lineáris narratívába rendezi auschwitzi emlékeit és értelmezi a múlt eseményeit és a kortárs társadalmi jelenségeket. A kórházi kezelése miatt a 
társasutazásról lemaradt interjúalany részletesen, elejétôl végéig meséli el a saját történetét.

Összefüggố narratívává alakítja, mint aki már sokszor elmesélte. A nố a Kádár-korszakban tabunak számító jelenkori antiszemitizmusról beszél, arról, hogy a holokausztot életre hívó rasszizmus, gyúlölet nem múlt el a magyar társadalomból. Az antiszemitizmustól való félelmét aláhúzza, hogy anonimitásban marad és félhomályos világításban csak körvonalaiban látható a képen. A rejtôzködést, a zsidó származás elrejtését egy másik láthatatlan szereplő ismétli meg. Az utazáson részt vevô egyik házaspár arra panaszkodik, hogy hiába vitték el lányukat Auschwitzba, hogy emlékezzen és elfogadja zsidó identitását, éppen ellenkezô hatást váltott ki belôle az utazás, elbújt a kamera elól, mert leplezni igyekszik osztálytársai és barátai elól zsidó származását.

A film fố eseménye a zarándoklatként értelmezhetô utazás Budapestrôl Auschwitzba. A magyar zsidók többségét elpusztító koncentrációs tábor felkeresése a túlélôk által több módon is értelmezhetô: van, aki emlékezni akar, van, aki múzeumként tekint rá, van, aki a leszármazottaknak akarja megmutatni családja szenvedéseinek és pusztulásának helyszínét. Báron György kvázi szakrális jelentést tulajdonít a holokausztfilmekben visszatérō utazásmotívumnak: „maga Auschwitz is - szó szerint és metaforikusan - utazás az emberi létezésból a nem-emberibe, a valóságon túliba, a kárhozat színterére. [...] A helyszín újbóli és újbóli felkeresésében kétségkívül ott rejlik a szakralitás motívuma, amelyben Auschwitz egyfajta kegyhelyként létezik, ám ugyanakkor a megtörténtek valóságosságára is figyelmeztet”. ${ }^{[52]}$

Bár Auschwitz kétségtelenül kegyhelyként is funkcionál a Társasutazás túlélôi és leszármazottai számára, ahol leróják kegyeletüket halottaik előtt, mégsem szabad az utazásnak kizárólagosan szakrális jelentést tulajdonítanunk. Ahogy például Dominick LaCapra írja, a holokauszt szakralizálása tabukkal veszi körbe az ábrázolását, és „egy kvázi-teológiai szituációt eredményez, amelyben a problémák elvesztik minden specifikusságukat azáltal, hogy egyszerre vannak mindenütt és nincsenek sehol”. ${ }^{[53]}$ A túléloók Auschwitzba utazása pszichológiai szempontból vizsgálva a poszttraumás szindróma ismétlési kényszereként is, az eredeti traumatikus utazás újrajátszásaként is értelmezhetô, hiszen „a trauma valami olyasmi, mint a kényszeres visszatérés a bûntett színhelyére”[54]. A visszatérés „a történtek értelmi, érzelmi átdolgozásának”"[55] eszköze lehet, amely a valódi jóvátételhez vezet. Az utazásról végül lemaradt, interjút adó nô motivációja ezt a pszichológiai értelmezést támasztja alá, ô a megértés szándékáról beszél, hogy negyven év után meg akarta tudni, mi történt vele húsz éves korában. A többi megszólaló töredékesen reflektál Auschwitzba utazásuk értelmére egymással folytatott párbeszédjeikben, s ki az emlékekkel való szembesülést, ki az elpusztított szeretteik elốtti megemlékezést, ki a vezeklést, ki a zsidó identitás következő nemzedékekre történő átörökítését említi saját motivációjaként.

A film már a címében is hangsúlyozza az utazás, s ebból eredôen a múlt felidézésének és újraélésének közösségi jellegét. Az emlékek a turistaút alkalmi csoportjában, ám a holokauszttúlélók sorsközösségében osztozva szakadnak fel. Kai Erickson a kollektív traumát elszenvedó egyén és a közösség kapcsolatát azzal a kettôsséggel jellemzi, hogy az áldozat egyszerre vonul vissza önmagába és nehezedik rá a trauma magányos teherként, másrészt „a megosztott trauma a közösségiség forrásaként is szolgálhat éppen úgy, ahogy a közös nyelv vagy a közös háttér. Lelki 
rokonság, identitástudat rejlik ebben."[56] A holokauszt átélt eseményeinek kibeszélése az elsô közösségi esemény, a közös ebéd során kezdôdik meg, s ha már egyszer átszakadt az emlékek gátja, akkor nem áll meg a beszélgetés, a buszon folytatódik, Auschwitzba érkezve pedig már a konkrét helyszínekhez kapcsolódva idézik fel emlékeiket a túlélôk. Az emlékek minél pontosabb közös felidézése - akár egymás helyreigazításával is - egyfajta terápia, mert nem a fájdalomnak adják át magukat, hanem a részletek rekonstrukcióján keresztül az események feldolgozásának.

„De mi ez a ragaszkodás a kínos - és kínzó - részletekhez, ahelyett, hogy mihamarább elfelejteni igyekeznénk ôket?" - kérdezi Kertész Imre. ${ }^{[57]}$ Ezt a kérdést teszi fel az egyik asszony is, aki arról beszél, hogy az ôt évrôl évre meglátogató ausztráliai rokonával is minden alkalommal a holokauszt eseményeit idézik fel. A magyarázat az áldozatot el nem engedô trauma természetében rejlik. A poszttraumás stressz zavarban „a múlt megsemmisítô erejú eseményei tolakodó képekben és gondolatokban ismétlődô módon hatalmukba kerítik azt, aki átélte ôket." ${ }^{[58]}$ Kertész Imre rámutat a szenvedéshez és gyászhoz való ragaszkodás értékmozzanatára, ami a megszállott emlékidézés egyik lehetséges oka. A túlélô a szabadulásra vágyik, ám a feloldozás lehetôsége és az események megértése éppen a múlttal való szembenézésben rejlik, vagy, ahogy Kertész fogalmaz, „a szabadulás egyetlen útja mindenképp az emlékezésen keresztül vezet”. ${ }^{[59]}$

A múlt rekonstrukciójának racionális válaszát megszakítja a kivégzőfallal való találkozás élménye, ami elnémítja az addig viszonylag nyugodtan beszélgetô túlélóket. Amint a csoporttal utazó rabbi egy héber siratódalt kezd énekelni, a kivégzőfal siratófallá lényegül át. Az államszocializmus évtizedei alatt elfelejteni kényszerült zsidó identitáselemek feltörô emléke erôs érzelmekkel telíti a halott rokonok, ismerôsök és az egész elpusztított zsidó közösség megsiratásának aktusát. Az egyéni gyász kollektív gyásszá formálódik, és a társasutazás résztvevői sorsközösséggé válnak. A siratás közösségéból idővel kiszakad egy-egy túlélő, aki a feltörô érzelmeit egyedül szeretné megélni, és magányosan kóborol sírva a tábor területén. A film érzelmi csúcspontját követôen a túlélôk magukba mélyedve utaznak tovább a buszon Birkenauba, ahol keresik a saját városuk, térségük emlékhelyeit, melyekre elhelyezhetik a gyász köveit. A csoport tagjai a tábor területét elhagyva kezdenek közösen reflektálni arra, hogy mi történt és hogyan történhetett meg velük, ami 1944-ben megtörtént, s ezzel katalizálják a néző szembenézését és felelősségvállalását a holokauszttal kapcsolatban. A film a trauma tudatos megértésének és érzelmi elsajátításának útjaként reprezentálja a társasutazás történetét, amelyben a kezdeti hallgatást az emlékek intenzív feltörése és közösségi kibeszélése követi, ami katartikus erejú siratásba torkollik és a fájdalom intenzív érzelmi átélésétôl eltávolodva racionális értelemkereséssel ér véget. 


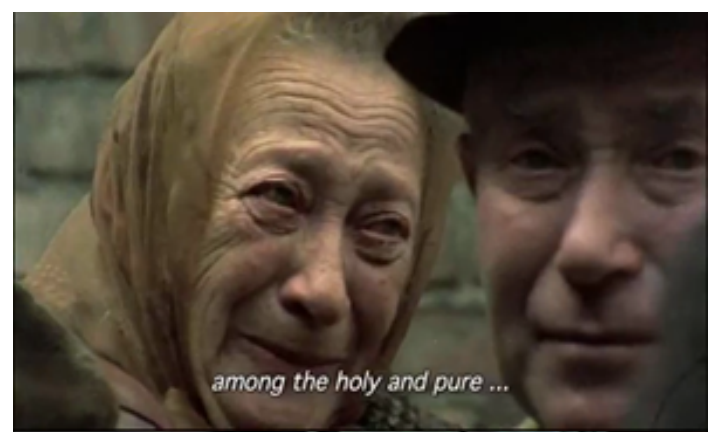

Társasutazás

A zarándoklat megrendítô, patetikus, kvázi szakrális érzelmeit a rendezó groteszk mozzanatokkal állította ellentétbe. Gazdag értelmezésében az auschwitzi turistáskodás maga az ellentmondás, amire a társasutazás szokásos kellékeinek (az idegenvezetôk szövege, a programszervezés technikája és kommunikációja) bemutatásával hívja fel a figyelmet. Az auschwitzi utazás zsidó túlélők számára szakrális jellegét kontrasztba hozza a turistáskodás megszokott performatív aktusaival, így például azzal, hogy egy fiatal kétgyermekes pár érzelemmentesen pózol a birkenaui emlékhelyen. A jelenet groteszk minôségét erôsíti, hogy a fényképezkedés hátterében kisebb baleset történik a társasutazás egyik idôs nôi tagjával, aki belelép egy gödörbe és elesik. Az elsôre banálisnak ható esemény a gondoskodás és kíváncsiskodás hétköznapi tevékenységei felé tereli a pár pillanattal korábban megindultan emlékező túlélôket, és enyhíti az azt megelózô események komorságát. A jelenet lassanként azonban oda fejlódik, hogy a múlt rettenetét groteszk formában teszi jelenvalóvá. Az asszony hangos ijedelme, hogy a csoport itt hagyja ôt, és ô Auschwitzban ragad, az egykori traumatikus élmény felelevenedésére, az emlék újraélésére utal. A baleset elôhívja az idôs nôbôl a rettegést, hogy a múlt újra megtörténhet, hogy ismét nem mehet haza Auschwitzból, nem szabadulhat a trauma örök jelenéból. Murai és Tóth rámutatnak a jelenet harmadik, önreflexív értelmére, ugyanis az elesett idôs asszony segítségére siet maga a rendezó is. [ ${ }^{60]}$ Azzal, hogy Gazdag Gyula belép a képbe, példát ad arra, hogy a megörökítésnél, a múvé formálásnál lényegesebb a szemtanú erkölcsi kötelessége, az embertársak iránti szolidaritás kifejezése, ami a holokauszt során elmaradt. 


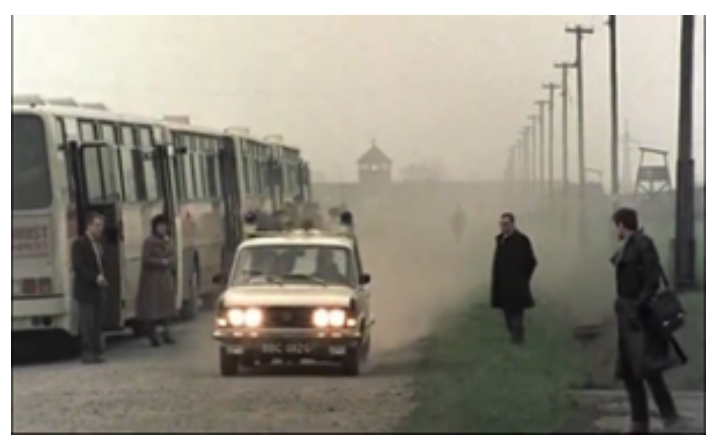

Társasutazás

A film végsố kicsengését az antiszemitizmus hangsúlyozása adja meg. A félhomályban ülô nô baljós gondolata zárja a filmet, miszerint ha Hitlert nyilvánosan lehet éltetni Magyarországon, akkor indokolt a félelme és rejtózködése. A Társasutazás záróképe az - akkor még bemutatás elôtt álló - Shoah befejezésének groteszk változata (a vonatok helyett a buszok mennek az úton, és viszik zsidó utasaikat), szintén a holokauszt megismétlódésének lehetôségére figyelmeztet.

\section{Konklúzió}

Az államszocializmus idején készült dokumentumfilmek a traumatikus élmény megélésének szerkezeti egyezéseire mutattak rá, melyeket az eltelt idó és a kulturális-politikai kontextus különböző jelentésekkel ruházott fel. A három utazás egyaránt a múlttal való találkozáshoz és a traumatikus élmény újraéléséhez vezetett. A megszüntethetetlen fájdalom a múlttal való közvetlen találkozás pillanatában sírásban szakadt fel: az elvesztett arc megpillantásakor, az elvesztett ház észrevételekor és Auschwitzban a siratófallá alakult kivégzőfal kollektív emlékhelyével való találkozáskor. A három film keletkezési idôszaka, a Kádár-korszak emlékezetpolitikájában tapasztalható lassú oldódás ugyanakkor erôsen befolyásolta a holokauszt traumájának dokumentumfilmes ábrázolási lehetôségeit, a trauma feldolgozásának lehetôségét. A három film gyártás- és recepciótörténete világosan mutatja, a Kádár-korszakban idôvel egyre nyíltabban lehetett beszélni a valóság hủ tükrének tekintett dokumentumfilmekben is a deportálások történetérôl, a zsidók genocídiumáról, múlt- és jelenbéli antiszemitizmusról, amely a holokauszt traumájával tudatosabban szembenézô magatartásformák reprezentációját eredményezte, és a tanúságtételnek nagyobb teret engedô reprezentációs formákhoz vezetett. A hatvanas évek elején, a holokauszt viszonylagos közelségében a politikailag is erősen motivált felejtéskényszer hatása alól átmenetileg kiszabadulva a túlélók és szemtanúk nem a történtek megértésére és saját zsidó identitásuk újragondolására, hanem még valódi jóvátételre vágytak, és a filmes ábrázolás is a jóvátételre, az arc előhívására tett kísérletet, amelyre mindenki rávetíthette saját elvesztett lánya, felesége, unokája arcát. A nyolcvanas évek elején már megjelenhetett a nem fikciós ábrázolásban is 
a zsidóság kérdése, a múltbéli és jelenkori antiszemitizmus, a magyarság holokauszttal kapcsolatos felelôsségének megértése és megértetése, a zsidóság és a holokauszt tabusításának problémája. Az emlékezés és a beszéd lehetôségével összefüggésben, a deportálások után negyven évvel már analitikusabb a viszony a traumatikus múlthoz, kevésbé erôs a személyes és társadalmi elfojtás kényszere, emiatt kevesebb a törés, elhallgatás az emlékezésben. A jóvátétel igénye sem kötődik emiatt a valóságos, materiális jóvátételhez, hanem szimbolikus síkra terelődik: a megbékélés és az emlékezés kettôsségében ölt testet.

1. Jelen írás korábbi angol nyelvû́ tanulmányom kibővített, átdolgozott változata: Journeys to the Past. Hungarian Holocaust Documentaries in the Kádár regime. Studies in Eastern European Cinema. Special Issue on Eastern European Documentary, 2018. https://doi.org/10.1080/2040350X.2018.1499351

2. Des Pres, Terrence: Holocaust Laughter? In Writing and the Holocaust. Szerk. Lang, Berel. New York, Holmes and Meier, 1988. 216-233.

3. Kisantal Tamás: Túléló történetek. Ábrázolásmód és történetiség a holokauszt mû́vészetében. Budapest, Kijárat, 2009. 47.

4. Nichols, Bill: Representing Reality. Issues and Concepts in Documentary. Bloomington, Indiana University Press, 1991. 3-4.

5. Meek, Allen: Trauma and Media. London - New York, Routledge, 2010. 158-159.

6. Daniels-Yeomans, Finn: Trauma, affect and the documentary image: towards a nonrepresentational approach. Studies in Documentary Film, 2017. 11.2. 1-19. 4.

7. Szirák Péter: Magyar-zsidó sors. Tiltás, szokás és kezdeményezés a hetvenes-nyolcvanas évek irodalmi köztudatában. In Mû̃vészet és hatalom. A Kádár-korszak múvészete. Szerk. Kisantal Tamás - Menyhért Anna. Budapest, JAK - L'Harmattan, 2005. 55-67. 59.

8. Kisantal: i. m. 87-97.

9. Insdorf, Annette: Indelible Shadowes. Film and the Holocaust. 3. kiadás. Cambridge, Cambridge University Press, 2003. 300.

10. Olin, Margaret: Lanzmann's Shoah and the Topography of the Holocaust Film. Representations, 1997/57. 123. 8.

11. Murai András - Tóth Eszter Zsófia: Hogyan képzeljük el? A holokauszt emlékezete és a hely rekonstrukciója dokumentumfilmekben. Korall, 2010/41. 81-96. 85.

12. Uo. 86.

13. György Péter: Talán még nem késô. In uố: Kádár köpönyege. Budapest, Magvetô, 2005. 101-116. 104.

14. Gyốri Szabó Róbert: A kommunizmus és a zsidóság az 1945 utáni Magyarországon. Budapest, Gondolat, 2009. 285.

15. Varga Balázs: Hiányjel. Zsidó sorsok magyar filmen. In Minarik, Sonnenschein és a többiek. Zsidó sorsok magyar filmen. Szerk. Surányi Vera, Szombat, Budapest, 2001. 24-35.

16. Sárközy Réka: Elbeszélt múltjaink. A magyar történelmi dokumentumfilm útja. 1956-os Intézet - L'Harmattan, Budapest, 2011. 123-125.

17. Uo.

18. Hajdú Eszter: Itélet Magyarországon. Egy politikailag érzékeny film elkészitése Magyarországon rendezôi tapasztalataim alapján. DLA disszertáció. Budapest, Színház- és Filmmúvészeti Egyetem, 2016. 99.

19. Alexander, Jeffrey C.: Trauma. A Social Theory. Cambridge, Polity Press, 2012. Magyarul: Alexander, Jeffrey C.: Holokauszt és trauma. Morális univerzalizmus Nyugaton. Ford. Fáber Ágoston - Gyimesi Zoltán - Szász 
Anna Lujza. In Transznacionális politika és a holokauszt emlékezettörténete. Szerk. Szász Anna Lujza -

Zombory Máté. Budapest, Befejezetlen Múlt Alapítvány, 2014. 66-147. 81-82.

20. Kisantal: i. m. 117.

21. György Péter: Apám helyett. Budapest, Magvető, 2011. 236.

22. Wieviorka, Annette: The Era of the Witness. Ford. Jared Stark. Ithaca, Cornell University Press, 2006.

23. Alexander: i. m. 95-107.

24. Komoróczy Géza: A zsidók története Magyarországon II. Budapest, Kalligram, 2012. 1042.

25. Tamás István: Filmekról. Népszabadság, 1964. március 6. 9.; Nemes Károly: A magyar filmmúvészet története 1957 és 1967 között. Budapest, Magyar Filmtudományi Intézet és Filmarchívum, 1978. 327.

26. Lásd például: „A film azonban az egészet közvetlenül átélhetôvé teszi. Részeseivé válunk a soha egészen be nem gyógyult sebeknek, az ügy kapcsán elszabadult pokol összes kínjának és fájdalmának, fültanúi a felszakadó és elcsukló félmondatoknak.” Maár Gyula: Nádasy László: Éva. Filmvilág, 1964/3. 10.

27. Rózsa László: Kicsoda Éva Krcz? Népszabadság, 1962. október, 20.290. 10-11.

28. LaCapra, Dominick: History and Memory after Auschwitz. London - Ithaca, Cornell University Press, 1998. 89.

29. Felman, Shoshana: In an Era of Testimony: Claude Lanzmann's Shoah. Yale French Studies. 50 Years of Yale French Studies: A Commemorative Anthology. Part 2: 1980-1998, 2000/97. 103-150.

30. Caruth, Cathy: Introduction. In Trauma: Explorations in Memory. Szerk. Caruth, Cathy. Baltimore London, John Hopkins University Press, 1996. 153.

31. Herman, Judith Lewis: Trauma és gyógyulás. Az erôszak hatása a családon belüli bántalmazástól a politikai terrorig . Budapest, Háttér Kiadó - Kávé Kiadó - NANE Egyesület, 2003. 178.

32. „Valahogy úgy éreztem, hogy ebben a bûnben én is részes voltam, attól függetlenül, hogy nem voltam benne akkor tudós, ugye, ezekben a dolgokban.”

33. Somogyi Gyula: Dekonstrukció és etika között. A trauma alakzatai Shoshana Felman és Cathy Caruth írásaiban. Studia Litteraria. 2011/3-4. 20-35. 25.

34. Didi-Huberman, Georges: Túl a feketén. Levél Nemes Lászlóhoz, a Saul fia rendezójéhez. Ford. Forgách András. Pécs, Jelenkor, 2016. 51.

35. Pintér Judit Nóra: A nem múló jelen. Trauma és nosztalgia. Budapest, L’Harmattan, 2014. 82.

36. Felman: i. m. 149.

37. Laub, Dori: Truth and testimony. The process and the struggle. In Trauma: Explorations in Memory. Szerk. Cathy Caruth. Baltimore - London, John Hopkins University Press, 1996. 61-75. 74.

38. Szekfü András: Beszélgetés B. Révész Lászlóval A látogatás címú filmjének vetítése kapcsán a 100 magyar dokumentumfilm sorozatban. 2015. július 9. https://www.youtube.com/watch?v=dJ5CVunrQik

39. Összesen 17 ezer nézô 442 elôadáson. (Gombár József: A magyar játékfilmek nézôszáma és forgalmazási adatai 1948-1987. Budapest, MOKÉP, 1987.)

40. Gantner Ilona: A látogatás. Népszava, 1982. december 2. 6.

41. Az élmény közvetett leírása az alábbi regényben olvasható: Bruck Edith: Hány csillag az égen? Ford. Barna Mária. Budapest, Európa, 2015.

42. Wiesel, Elie: The Last Return. In uô: Legends of Our Time. New York, Schocken Book, 1982. 110-130. 113.

43. Uo. 130.

44. Améry, Jean: Mennyi haza kell az embernek? In uô: Túl bünön és bünhödésen. Ford. Blaschtik Éva. Budapest, Múlt és Jövő Kiadó, 2002. 64-87. 65. 
45. Uo. 73 .

46. Az államszocialista magyar társadalomban létezô rasszizmus tagadását, tabusítását a kultúrpolitikában jelzi, hogy a stúdióvezetô ezt a mondatot igyekezett kivágatni a filmbôl, mint B. Révész László - részben egy vele folytatott személyes beszélgetésemben, részben nyilvános fórumon is - elárulta. (Szekfü: i. m.)

47. „Kedves Edit! Légy egyszerre kitûnô magyar, kitûnő olasz és igyekezz felülrôl nézni zsidó voltodat!”

48. Pintér: i. m. 83.

49. 856 elôadás, 51 ezer nézô moziban. (Gombár: i. m. 143.)

50. Lásd például: Sas György: Társasutazás. Népszava, 1985. február 21. 6.

51. Cole, Tim: Holocaust Tourism: The Strange yet Familiar/the Familiar yet Strange. In Revisiting Holocaust Representation in the Post-Witness Era. Szerk. Diana I. Popescu - Tanja Schult. New York, Palgrave MacMillan, 2015. 93-106. 98.

52. Báron György: Egyszer volt... Magyar dokumentumfilmek a holocaustról. Filmvilág, 2014/10. 10-13. 12.

53. LaCapra, Dominick: Representing the Holocaust. History, Theory, Trauma. Ithaca and London, Cornell University Press, 1994. 210.

54. Seltzer, Mark: Wound Culture: Trauma in the Pathological Public Sphere. October, 1997/80. 3-26. 11.

55. Pintér: i. m. 42.

56. Erickson, Kai: Notes on Trauma and community. In Trauma: Explorations in Memory. Szerk. Cathy Caruth. Baltimore - London, John Hopkins University Press, 1996. 186.

57. Kertész Imre: Kié Auschwitz? In uô: A számüzött nyelv. Budapest, Magvető, 2001. 240-251. 241.

58. Caruth: i. m. 151.

59. Kertész: i. m. 243.

60. Murai-Tóth: i. m. 87.

\section{Irodalomjegyzék}

- Alexander, Jeffrey C.: Trauma. A Social Theory. Cambridge, Polity Press, 2012. Magyarul: Alexander, Jeffrey C.: Holokauszt és trauma. Morális univerzalizmus Nyugaton. Ford. Fáber Ágoston - Gyimesi Zoltán - Szász Anna Lujza. In Transznacionális politika és a holokauszt emlékezettörténete. Szerk. Szász Anna Lujza - Zombory Máté. Budapest, Befejezetlen Múlt Alapítvány, 2014. 66-147.

- Améry, Jean: Mennyi haza kell az embernek? In uô: Túl bûnön és bûnhôdésen. Ford. Blaschtik Éva. Budapest, Múlt és Jövố Kiadó, 2002. 64-87.

- Báron György: Egyszer volt... Magyar dokumentumfilmek a holocaustról. Filmvilág, 2014/10. $10-13$.

- Bruck Edith: Hány csillag az égen? Ford. Barna Mária. Budapest, Európa, 2015.

- Caruth, Cathy: Introduction. In Trauma: Explorations in Memory. Szerk. Caruth, Cathy. Baltimore - London, John Hopkins University Press, 1996.

- Cole, Tim: Holocaust Tourism: The Strange yet Familiar/the Familiar yet Strange. In Revisiting Holocaust Representation in the Post-Witness Era. Szerk. Diana I. Popescu - Tanja Schult. New York, Palgrave - MacMillan, 2015. 93-106. https://doi.org/10.1057/9781137530424_7

- Daniels-Yeomans, Finn: Trauma, affect and the documentary image: towards a 
nonrepresentational approach. Studies in Documentary Film, 2017. 11.2. 1-19.

https://doi.org/10.1080/17503280.2017.1281719

- Des Pres, Terrence: Holocaust Laughter? In Writing and the Holocaust. Szerk. Lang, Berel. New York, Holmes and Meier, 1988. 216-233.

- Didi-Huberman, Georges: Túl a feketén. Levél Nemes Lászlóhoz, a Saul fia rendezójéhez. Ford. Forgách András. Pécs, Jelenkor, 2016.

- Erickson, Kai: Notes on Trauma and community. In Trauma: Explorations in Memory. Szerk. Cathy Caruth. Baltimore - London, John Hopkins University Press, 1996.

- Felman, Shoshana: In an Era of Testimony: Claude Lanzmann's Shoah. Yale French Studies. 50 Years of Yale French Studies: A Commemorative Anthology. Part 2: 1980-1998, 2000/97. 103-150. https://doi.org/10.2307/2903217

- Gantner Ilona: A látogatás. Népszava, 1982. december 2.

- Gáspár Ferenc: Az Eichmann-per és a magyar politikai vezetés. Szombat, 2002/11. http://www.szombat.org/archivum/az-eichmann-per-es-a-magyar-politikai-vezetes$\underline{1352774054}$

- Gombár József: A magyar játékfilmek nézószáma és forgalmazási adatai 1948-1987. Budapest, MOKÉP, 1987.

• György Péter: Talán még nem késô. In uố: Kádár köpönyege. Budapest, Magvetô, 2005. 101-116.

- György Péter: Apám helyett. Budapest, Magvető, 2011.

- Gyôri Szabó Róbert: A kommunizmus és a zsidóság az 1945 utáni Magyarországon. Budapest, Gondolat, 2009.

- Hajdú Eszter: Itélet Magyarországon. Egy politikailag érzékeny film elkészítése Magyarországon rendezối tapasztalataim alapján. DLA disszertáció. Budapest, Színház- és Filmmúvészeti Egyetem, 2016.

- Herman, Judith Lewis: Trauma és gyógyulás. Az erôszak hatása a családon belüli bántalmazástól a politikai terrorig. Budapest, Háttér Kiadó - Kávé Kiadó - NANE Egyesület, 2003.

- Insdorf, Annette: Indelible Shadows. Film and the Holocaust. Third Edition. Cambridge, Cambridge University Press, 2003. https://doi.org/10.1017/CBO9780511615276

- Kertész Imre: Kié Auschwitz? In uô: A számúzött nyelv. Budapest, Magvetô, 2001. 240-251.

- Kisantal Tamás: Túlélố történetek. Abrázolásmód és történetiség a holokauszt müvészetében. Budapest, Kijárat, 2009.

- Komoróczy Géza: A zsidók története Magyarországon II. Budapest, Kalligram, 2012.

- LaCapra, Dominick: Representing the Holocaust. History, Theory, Trauma. Ithaca and London, Cornell University Press, 1994.

- LaCapra, Dominick: History and Memory after Auschwitz. London - Ithaca, Cornell University Press, 1998. https://doi.org/10.7591/9781501727450

- Laub, Dori: Truth and testimony. The process and the struggle. In Trauma: Explorations in Memory. Szerk. Cathy Caruth. Baltimore - London, John Hopkins University Press, 1996. 61-75.

- Maár Gyula: Nádasy László: Éva. Filmvilág, 1964/3.

- Meek, Allen: Trauma and Media. London - New York, Routledge, 2010.

- Murai András - Tóth Eszter Zsófia: Hogyan képzeljük el? A holokauszt emlékezete és a hely rekonstrukciója dokumentumfilmekben. Korall, 2010/41. 81-96. 
- Murányi Gábor: Visszafogott magyarok. $H V G$, 2007. október 6. 48.

- Nemes Károly: A magyar filmmúvészet története 1957 és 1967 között. Budapest, Magyar Filmtudományi Intézet és Filmarchívum, 1978.

- Nichols, Bill: Representing Reality. Issues and Concepts in Documentary. Bloomington, Indiana University Press, 1991.

- Olin, Margaret: Lanzmann's Shoah and the Topography of the Holocaust Film. Representations, 1997/57. 1-23. https://doi.org/10.2307/2928661

- Pintér Judit Nóra: A nem múló jelen. Trauma és nosztalgia. Budapest, L’Harmattan, 2014.

- Rózsa László: Kicsoda Éva Krcz? Népszabadság, 1962. október, 20.290. 10-11.

- Sas György: Társasutazás. Népszava, 1985. február 21. 6.

- Sárközy Réka: Elbeszélt múltjaink. A magyar történelmi dokumentumfilm útja. 1956-os Intézet L'Harmattan, Budapest, 2011.

- Seltzer, Mark: Wound Culture: Trauma in the Pathological Public Sphere. October, 1997/80. 326. https://doi.org/10.2307/778805

- Somogyi Gyula: Dekonstrukció és etika között. A trauma alakzatai Shoshana Felman és Cathy Caruth írásaiban. Studia Litteraria. 2011/3-4. 20-35.

- Szekfü András: Beszélgetés ifj. Nádasy Lászlóval az Éva A 5116 címú filmjének vetítése kapcsán a 100 magyar dokumentumfilm sorozatban. 2015. július 9 . https://www.youtube.com/watch?v=XOXCLm2x1Ac\&t=2755s

- Szekfü András: Beszélgetés B. Révész Lászlóval A látogatás címú filmjének vetítése kapcsán a 100 magyar dokumentumfilm sorozatban. 2015. július 9. https://www.youtube.com/watch?v=dJ5CVunrQik

- Szirák Péter: Magyar-zsidó sors. Tiltás, szokás és kezdeményezés a hetvenes-nyolcvanas évek irodalmi köztudatában. In Múvészet és hatalom. A Kádár-korszak múvészete. Szerk. Kisantal Tamás - Menyhért Anna. Budapest, JAK - L’Harmattan, 2005. 55-67.

- Tamás István: Filmekrôl. Népszabadság, 1964. március 6. 9.

- Varga Balázs: Hiányjel. Zsidó sorsok magyar filmen. In Minarik, Sonnenschein és a többiek. Zsidó sorsok magyar filmen. Szerk. Surányi Vera, Szombat, Budapest, 2001. 24-35.

- Wiesel, Elie: The Last Return. In uố: Legends of Our Time. New York, Schocken Book, 1982. 110-130.

- Wieviorka, Annette: The Era of the Witness. Ford. Jared Stark. Ithaca, Cornell University Press, 2006.

\section{Filmográfia}

- A látogatás (B. Révész László, 1982)

- Apa (Szabó István, 1966)

- Endlösung (Fehéri Tamás, 1984)

- Éva A 5116 (Nádasy László, 1964)

- Jelenlét (Jancsó Miklós, 1965)

- Jelenlét II. (Jancsó Miklós, 1978) 
- Két félidô a pokolban (Fábri Zoltán, 1961)

- Krónika (Sára Sándor, 1982)

- Nappali sötétség (Fábri Zoltán, 1962)

- Pócspetri (Ember Judit, 1982)

- Recsk (Böszörményi Géza - Gyarmathy Lívia, 1988)

- Shoah (Claude Lanzmann, 1985)

- Társasutazás (Gazdag Gyula, 1985)

- Törvénysértés nélkül (Gulyás Gyula, Gulyás János, 1988)

- Utószezon (Fábri Zoltán, 1967) 
(C) Apertúra, 2020. tavasz | www.apertura.hu

webcím: https://www.apertura.hu/2020/tavasz/stohr-visszateres-a-tett-szinhelyere-a-holokauszt-

traumaja-kadar-kori-magyar-dokumentumfilmekben/

https://doi.org/10.31176/apertura.2019.15.3.2

\section{(2)opertúro}

